\title{
Theoretical, Conceptual \& Empirical Perspectives on Consumer Satisfaction - A Review of Literature
}

\author{
Adeyemo, F.S. \\ Department of Business Administration \\ Caleb University \\ Imota, Lagos State, Nigeria \\ E-mail: feliciaadeyemo@yahoo.com
}

\begin{abstract}
Customer satisfaction remains a leading goal in the operations of business enterprises. As the challenges of customer complaints and lack of satisfaction with goods and services increases, research is warranted into antecedents of these problems through proper literature review which provides baseline information on customer expectations and desires. In this paper, a critical review of literature on the theoretical, conceptual and empirical antecedents of customer satisfaction is carried out. Findings from the reviews showed that that customers purchase services are based on their needs and they have expectations that the purchased services will meet their needs. Customers in turn assess the service performance in accordance to how well it meets their expectations. Future work will examine how the findings from literature intertwine with productivity and effectiveness of service delivery.
\end{abstract}

Keyword: Theories, Concepts, Empirical Perspectives, Consumer Satisfaction and Services

Journal Reference Format:

Adeyemo,. F.S. (2018): The Relationship between Whistle Blowing and Perceived Retaliation in Nigeria Federal Civil Service.

Humanities, Management, Arts, Education \& the Social Sciences Journal. Vol. 6. No. 3, Pp 79-92

Article DOI: dx.doi.org/10.22624/AIMS/HUMANITIES/V6N3P9

Available online at www.humanitiesjournal.org

\section{INTRODUCTION}

Customer satisfaction, as a construct, has been fundamental to marketing for over three decades. As early as 1960, Keith (1960) defined marketing as "satisfying the needs and desires of the consumer". Hunt (1982) reported that by the 1970 s, interest in customer satisfaction had increase to such an extent that over 500 studies were published. This trend continued and by 1992, Peterson and Wilson estimated the amount of academic and trade articles on customer satisfaction to be over 15,000. Several studies have shown that it costs about five times to gain a new customer as it does to keep an existing customer (Naumann, 1995) and these results into more interest in customer relationships. Thus, several companies are adopting customer satisfaction as their operational goal with a carefully designed framework. Hill and Alexander (2000) wrote in their book that "companies now have big investment in database marketing, relationship management and customer planning to move closer to their customers". Jones and Sasser (1995) wrote that "achieving customer satisfaction is the main goal for most service firms today". Increasing customer satisfaction has been shown to directly affect companies' market share, which leads to improved profits, positive recommendation, lower marketing expenditures (Reichheld, 1996; Heskett et al., 1997), and greatly impact the corporate image and survival (Pizam and Ellis, 1999). 


\subsection{Satisfaction}

Satisfaction as a process is the most widely adopted description of customer satisfaction and a lot of research efforts have been directed at understanding the process approach of satisfaction evaluations (Parker and Mathews, 2001). This approach has its origin in the discrepancy theory (Porter, 1961), which argued that satisfaction is determined by the perception of a difference between some standard and actual performance. Cardozo (1965); and Howard and Sheth (1969) developed the contrast theory, which showed that consumers would exaggerate any contrasts between expectations and product evaluations. Olshavsky and Miller (1972); and Olson and Dover (1979) developed the assimilation theory, which means that perceived quality is directly increasing with expectations. Assimilation effects occur when the difference between expectations and quality is too small to be perceived. Anderson (1973) further developed this theory into assimilation-contrast theory, which means if the discrepancy is too large to be assimilated then the contrast effects occur. The assimilation-contrast effects occur when the difference between expectations and quality is too large to be perceived and this difference is exaggerated by consumers.

\section{THEORETICAL FRAMEWORKS}

According to Parker and Mathews (2001), the most popular descendant of the discrepancy theories is the expectation disconfirmation theory (Oliver, 1977, 1981), which stated that the result of customers' perceptions of the difference between their perceptions of performance and their expectations of performance. Positive disconfirmation leads to increased satisfaction, with negative disconfirmation having the opposite effect. Yi (1990) expressed that customers buy products or services with pre-purchase expectations about anticipated performance, once the bought product or service has been used, outcomes are compared against expectations. If the outcome matches expectations, the result is confirmation. When there are differences between expectations and outcomes, disconfirmation occurs. Positive disconfirmation occurs when product or service performance exceeds expectations. Therefore, satisfaction is caused by positive disconfirmation or confirmation of customer expectations, and dissatisfaction is the negative disconfirmation of customer expectations (Yi, 1990). While several studies support the disconfirmation paradigm, others do not. For instance, Churchill and Surprenant (1982) found that neither disconfirmation nor expectations had any effect on customer satisfaction with durable products.

Weiner (1980, and 1985); and Folkes (1984) proposed the attribution theory, which stated that when a customer purchases a product or service, if the consumption is below expectation, the customer is convinced that the supplier causes the dissatisfaction. The complaining customer is focused on restoring justice and the satisfaction outcome is driven by perceived fairness of the outcome of complaining.

Westbrook and Reilly (1983) proposed the value-percept theory, which defines satisfaction as an emotional response caused by a cognitive-evaluative process, which is the comparison of the product or service to one's values rather than an expectation. So, satisfaction is a discrepancy between the observed and the desired.

Fisk and Young (1985); Swan and Oliver (1985) proposed the equity theory, which stated that individuals compare their input and output ratios with those of others and feel equitable treated. Equity judgement is based on two steps; first, the customer compares the outcome to the input and secondly, performs a relative comparison of the outcome to the other party. 
The outcome approach of the customer satisfaction is defined as the end-state satisfaction resulting from the experience of consumption. This post- consumption state can be an outcome that occurs without comparing expectations (Oliver, 1996); or may be a cognitive state of reward, an emotional response that may occur as the result of comparing expected and actual performance or a comparison of rewards and costs to the anticipated consequences (Vavra, 1997, p. 4).

Furthermore, Parker and Mathews (2001) expressed that attention has been focused on the nature of satisfaction of the outcome approach which include:

(1). Emotion - Satisfaction is viewed as the surprise element of product or service purchase and or consumption experiences (Oliver, 1981), or is an affective response to a specific consumption experience (Westbrook and Reilly, 1983). This acknowledges the input of comparative cognitive processes but goes further by stating that these may be just one of the determinants of the affective "state" satisfaction (Park and Mathews, 2001).

(2) Fulfillment -The theories of motivation state that people are driven by the desire to satisfy their needs (Maslow, 1943) or by their behaviour aimed at achieving the relevant goals (Vroom, 1964). However, satisfaction can be either way viewed as the end-point in the motivational process. Thus "consumer satisfaction can be seen as the consumer's fulfillment response" (Rust and Oliver, 1994, p. 4).

(3) State - Oliver (1989) expressed that there are four framework of satisfaction, which relates to reinforcement and arousal. "Satisfaction-as-pleasure" results from positive reinforcement, where the product or service is adding to an aroused resting state, and "satisfaction-as-relief" results from negative reinforcement .In relation to arousal, low arousal fulfillment is defined as "satisfaction-as contentment", a result of the product or service performing adequately in an ongoing passive sense.

\subsection{Consequences of customer Satisfaction}

Naumann (1995) expressed that the reasons for measuring customer satisfaction may vary among companies, and the success of the measurement depends on if the measurement is incorporated into the firm's corporate culture or not. However, he suggested five reasons for measuring customer satisfaction or five important roles of customer satisfaction measurement: To get close to the customer - this will help to understand customers more, their needs, the attributes that are most important, and their effect on the customer's decision making, the relative importance of the attributes and the performance evaluation of the firm delivery of each attribute. This process helps to provide enabling communication with customers.

Measure continuous improvement - the important attributes of customers can be incorporated into the internal measurement to evaluate the value-added process in the company. This process involves comparing performance against internal standards (process control and improvement), and comparing performance against external standards (benchmarking).

To achieve customer-driven improvement - the data collected from customers can be developed into sources of innovations and this can help to achieve customer driven improvement. This requires a comprehensive database and not just records of sales. This process helps to identify opportunities for improvement (quality costing). 


\section{EMPIRICAL ANTECEDENTS}

Several empirical findings have shown that the application of customer satisfaction measurement often does not accomplish the objectives of the company and the reasons for this shortcoming are; Many organizations determine criteria for measurement internally without an accurate understanding of customer priorities (Hill, 1996). This measurement is based on the value defined by organizations and not by the customers, thereby providing wrong information. Many companies do not measure customer satisfaction as thorough as manufacture component and those who claim to do so, perform it an inadequate way (Hill and Alexander, 2000). Difficulty in translating the customer satisfaction data into action within the organization (Wiele et al., 2002)

Werth (2002) stated that many companies identify the level of customer satisfaction through;

Number of product or service support problems

Number of direct complaints by phone, email, etc

Number of returned products or services and the reason for their return, etc

Fečiková (2004) disagreed with this measurement procedure in that it is a measure of customer dissatisfaction (no satisfaction) and may provide wrong information with no possibility for product or service development and innovation. The criteria for measurement should be customer defined so as to collect, analyze the appropriate data and provide relevant information. Thus, to obtain the right information, efforts should be made to filter out the irrelevant information and concentrate on the valuable dimensions. A convenient tool to achieve this aim is to first conduct a simple pre-study and from this a more effective study can be created.

Therefore, for any company to achieve true customer satisfaction, there should be:

- Customer-oriented culture

- Customer-centered company

- Employee empowerment

- Process ownership

- Team building, and

- Partnering with customers and suppliers

- He further expressed that the measurement research technique include:

- Survey methodologies

- Focus groups

- Standardized packages

- Various computer softwares

However, these typical measurement techniques have some problems which include;

- Analytical - this involves techniques, formal procedures, systems, etc

- Behavioural - involves the attitudes, beliefs, perceptions, motivation, commitment and resulting behaviour of the people involved in the process.

- Organizational - involves the organizational structure, information flows, management style and corporate culture. 
Hill et al. (2003) expressed that one of the methods to measure customer satisfaction is through the simple frequency statistics of the Microsoft office Excel or that of the Statistical Package for Social Science (SPSS). Fečiková (2004) reported that there are other methods for customer satisfaction measurement and these include;

The indicator of customer satisfaction level

Hazes (1998) proposed that customer satisfaction could be measured as:

$\mathrm{I}_{\mathrm{CS}}=\underline{\underline{\mathrm{I}_{\mathrm{CSS}}}} \times 100[\%]$

Iocs

$\mathrm{I}_{\mathrm{cs}}=$ increasing customer satisfaction

$\mathrm{I}_{\mathrm{rcs}}=$ the real value of the customer satisfaction index which is used routinely as a tool of customer satisfaction measurement.

$\mathrm{I}_{\mathrm{ocs}}=$ the optimum value of such an index.

3.1 The index of satisfaction

Bhave (2002) proposed that to obtain the index of satisfaction, the satisfaction score is multiplied by the corresponding weighting factor to produce weighting score. The index of satisfaction is the sum of the weighting score. The overall satisfaction index of any company is the average of every respondent's individual satisfaction index.

\subsection{ACSM Method of Customer Satisfaction Measurement}

The American Customer Satisfaction Model (ACSM) method is a set of causal equations that link: customer expectations perceived quality, and perceived value to customer satisfaction (ACSI).

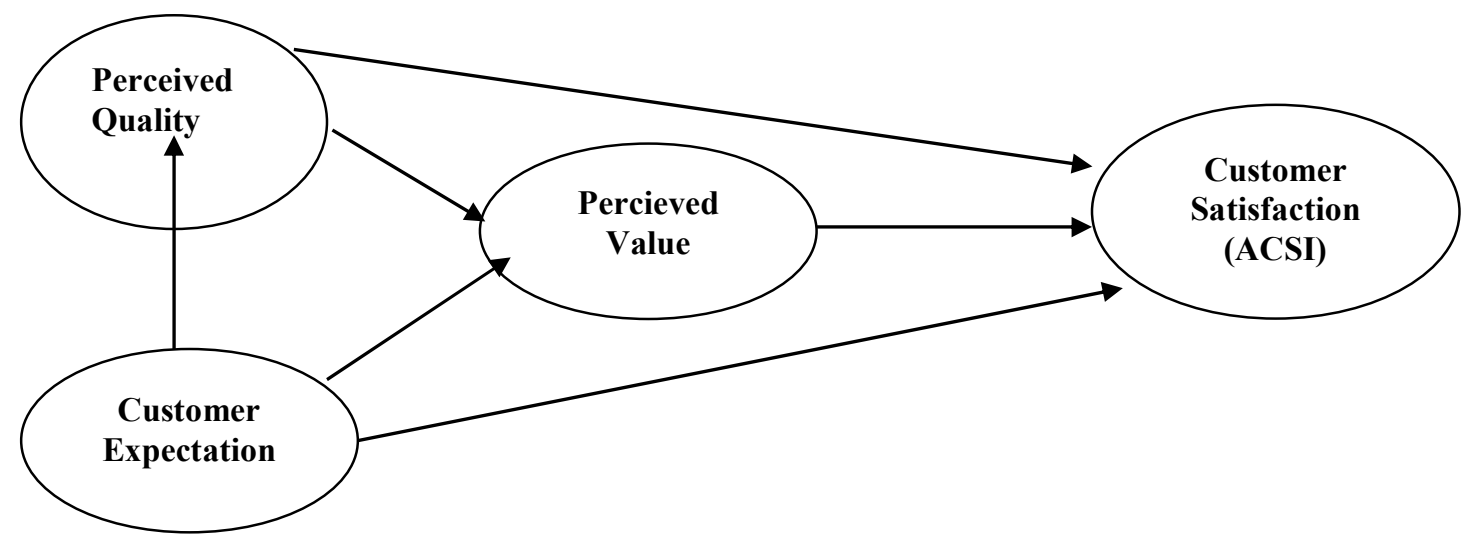

Fig. 2.1 The ACSM model of customer satisfaction measurement by Fornell et al.1996

Several empirical studies done on the assessment of customer satisfaction levels include: Gerpott et al. (2001) investigated the customer satisfaction level of 684 residential customers of mobile operators in Germany using the frequency distribution, the results showed that $28 \%$ of the respondents were completely satisfied and 6.3\% were slightly satisfied or not satisfied. Turel and Serenko, 2006, assessed customer satisfaction level of 210 young adult mobile subscribers in Canada by adapting the American Customer Satisfaction Model, the result obtained was $54.67 \%$. This score was relatively low compared to the $65 \%$ obtained by ACSI organization for the USA in 2004. 
Fornell (1992) investigated customer satisfaction with 100 corporations in over 30 industries in Sweden and expressed that the benefits of customer satisfaction include the following; highly satisfied customers -

- Stay longer (i.e. prevent customer churn)

- Purchase more as the company introduces new products and upgrades existing products

- Talk favorably about the company and its products or services (helps to improve advertisement)

- Pay less attention to competing brands

- Less sensitive to price

- Offer product or service ideas to the company

- Cost less to serve than new customers because transactions are routine

- Enhances business reputation

These benefits make customer satisfaction and its measurement an important marketing construct, which is especially essential to the mobile telecoms industry in which the long-term links between operators and customers are of greater importance to business performance. Several research works have shown that customer satisfaction is positively associated with desirable business outcomes namely; Customer Loyalty, Customer Retention, and Customer Profitability. Gerpott et al. (2001) reported that these consequences are important goals for telecommunications operators to have superior economic success.

\subsection{Customer Loyalty}

Coyne (1989) stated that customer satisfaction has measurable impact on customer loyalty in that when satisfaction reaches a certain level; on the high side, loyalty increases dramatically; at the same time, when satisfaction falls to a certain point, loyalty reduces equally dramatically. Yi (1990) expressed that the impact of customer satisfaction on customer loyalty by stating that "customer satisfaction influences purchase intentions as well as post-purchase attitude". In other word, satisfaction is related to behavioural loyalty, which includes continuing purchases from the same company, word of mouth recommendation, increased scope of relationship. Fornell (1992) found out that there is a positive relationship between customer satisfaction and customer loyalty but this connection is not always a linear relation. This relationship depends on factors such as market regulation, switching costs, brand equity, existence of loyalty programs, proprietary technology, and product differentiation at the industry level. Jones and Sasser (1995) proposed that link between satisfaction and loyalty can be classified into four different groups: loyalist/apostle (high satisfaction, high loyalty), defector/ terrorist (low satisfaction, low loyalty), mercenary (high satisfaction, low loyalty), and hostage (low satisfaction, high loyalty).

\subsection{Customer Retention}

Several research works have shown that there is positive relationship between customer satisfaction and customer retention; customer satisfaction has a direct effect on customer retention (Rust and Subramaman, 1992); customer satisfaction is positively related to customer retention (Anderson and Sullivan, 1993); to retain a customer, it is necessary to satisfy him. Satisfied customer is more likely to return and stay with a company than a dissatisfied customer who can decide to go elsewhere (Ovenden, 1995); satisfaction leads to retention and the retention is not simply because of habit, indifference or inertia (Desai and Mahajan, 1998); customer retention is central to the development of business relationships, and these relationships depend on satisfaction (Eriksson and Vaghult, 2000); customer satisfaction is an antecedent of customer retention (Athanassopoulos, 2000); customer satisfaction is a central determinant of customer retention (Gerpott et al., 2001); customer satisfaction is positively related to customer retention and the effect varies by customer size and the customer's current level of satisfaction (Niraj et al., 2003). 


\subsection{Customer Profitability}

Research studies conducted by Gale (1992) and Fornell (1992) showed that higher customer satisfaction translates into higher than normal market share growth, the ability to charge a higher price, lower transaction costs, and a strong link to improved profitability. Nelson et al., (1992) also demonstrated that customer satisfaction is related to higher profitability and proved his findings statistically. Andersson et al., (1994) found a significant association between customer satisfaction and accounting return on assets. Ittner and Larckner (1996) found that shareholder value is highly elastic with respect to customer satisfaction. Fornell et al., 1996, found out that customer satisfaction is significantly related to firms' financial performance. The volume of business conducted with a firm is directly related to customer satisfaction, which in turns affect profitability (Ittner and Larcker, 1998).

\subsection{Internal Satisfaction}

Research works have shown the importance and the link of internal (employee) satisfaction to the external (customer) satisfaction. Hill and Alexander (2000) stated that there is a positive relationship between employee satisfaction and customer satisfaction and this is achieved in companies that practice employee motivation and loyalty. They reported that "employees that are more motivated to achieve customer satisfaction tend to be more flexible in their approach to their work, make fewer mistakes and use more initiative”. Fečiková (2004) conducted studies on the index method for customer satisfaction measurement with chairs in Slovakia and reported that the satisfaction of internal customers is one of the basic factors to satisfy the external customer. Thus, she suggested that employee motivation and loyalty can be achieved through:

- Daily leadership - Top management officials motivate others through their performance.

- Top management communicates their expectations to the employees.

- Development of competencies - feedback on employees performance, work efforts, opportunity for development and improvement of competencies.

- Corporation and employee retention, and

- Good working conditions

\section{SERVICE QUALITY}

Taylor and Baker (1994) and Rust and Oliver (1994) identified several factors that precede customer satisfaction and suggested that these factors strongly influence the extent of customer satisfaction. Some of these antecedents include:

\subsection{Clear Understanding of Customer Needs and Expectations}

The achievement of a strong customer satisfaction is closely related to the understanding customer needs and expectations (William and Bertsch, 1992). According to the Kano Model (2001), customer needs can be divided into:

Basic needs

Ovious needs of customers and if not met, he is dissatisfied, however meeting this needs may not be enough for customer satisfaction. Its satisfaction results in "must be quality". Expected needs - these are important needs that customers are fully aware of and satisfaction is expected in every purchase; their satisfaction creates "expected quality". 


\section{Excitement needs}

These are unconscious and unspoken needs of customers. By identifying and satisfying such needs, companies will have added large value to customers and can win loyal customers. This satisfaction creates "attractive quality".

\section{Complaint Management}

Albrecht and Zemke (1985) found that of the customers who register complaints, between $54 \%$ and $70 \%$ will do business again with the company if their complaints are resolved. This figure increases to $95 \%$ if the customer feels that the complaint was resolved promptly. Customers who have complained to a company and had their complaints satisfactorily resolved tell an average of five people about the good treatment they received. Hart, et al., 1990, reported that when the service provider accepts responsibility and resolves the problem when customers complain, the customer becomes "bonded" to the company.

McNeale (1994) found out that about 5\% of the dissatisfied customers actually complain to the appropriate companies but easily tell their friends, colleagues and acquaintances about their experiences. Thus, companies ought to be aware or routinely investigate how well or badly their customers are treated. Ovenden (1995) in his book about studies conducted on several companies in the UK, such as wholesaler, manufacturers, etc, argued that companies need to be aware how well or badly its customers are treated and that customers rarely complain and when they do, it might be too late to keep such customers.

Other suggested antecedents of customer satisfaction include: disconfirmation paradigm (Yi, 1990, and Szymanski and Henard, 2001); performance (Cadotte, et al., 1988, and Bolton and Drew, 1991); affects (Westbrook and Oliver, 1991 and Mano and Oliver, 1993); and equity (Oliver, 1993 and 1997). In summary, the relevance of this sub-section to this study is to Better understanding that customers assess service performance based on their past experiences, benefits received, service quality and how well queries and complaints are treated. Thus, customer satisfaction with the mobile services in Nigeria will be assessed based on network quality, billing, validity period and customer care support.

\section{DEMOGRAPHICS AND THEIR INFLUENCED ON CUSTOMER SATISFACTION}

The social identity theory proposed that attitudes are moderated by demographic, situational, environmental, and psychosocial factors (Haslam et al., 1993; Jackson et al., 1996; Platow et al., 1997). According to the social psychological theories, consumers' evaluations are moderated, or in some cases mediated, by personal feelings of equity in the exchange, disconfirmation between desires and outcomes, individual preferences, social comparisons, and other complex phenomena. These theories strongly suggest that differences in these phenomena among consumers influence their attitudes (Williams et al., 1998). Several empirical findings that have shown the relationship between demographic variables and satisfaction include:

Bryant et al. (1996) conducted a study on 400 companies using the American Customer Satisfaction Index (ACSI) and demonstrated that there is significant relationship and consistent differences in the levels of satisfaction among demographic groups: Sex - positively related to satisfaction and female customers are more satisfied than the male customers. Female of all ages are more satisfied than the male. Women are more involved with the process of purchase and possibly use the mobile phone more for relational purposes (social network device) while men use it for functional purposes (businesses, sales, etc). Age positively related to satisfaction but the relationship is not a straight line. Satisfaction increases with age. 
The major increase in satisfaction is seen within the age 55 and over. Income - the higher the income, the lower the satisfaction level. Location (type of area) - positively related to satisfaction. Customers living within metropolitan areas (central city and suburban areas) are less satisfied than those customers in nonmetropolitan areas.

Palvia and Palvia (1999) found out that age is a significant determinant of satisfaction with information technology industry. Oyewole (2001) in his research on customer satisfaction with airline services reported also that gender, occupation, education, and marital status have significant influence on customer satisfaction, while age and household income had no significant influence. Homburg and Giering (2001) conducted a study on German car manufacturers using LISREL notation and demonstrated that it is important to study demographic variables as determinants of customer behaviours. The results of their study showed that gender has significant moderating effect on satisfaction- loyalty relationship. Women are satisfied with sales process while men are satisfied with the impact of the product. Age showed a positive moderating effect and income had moderating influence with high income showing weaker effect and low income, high effect. Jessie and Sheila (2001) in their empirical work on patients' assessment of satisfaction and quality using factor analysis and regression, reported that age, beneficiary group, location, rank, service affiliation, education, marital status, race, gender, health status and number of visits (sociodemographic variables) have minimal influence on satisfaction

Ahmad and Kamal (2002) conducted a study on a commercial bank using a stepwise regression and demonstrated that there is negative significance between age and satisfaction. When age goes up, satisfaction levels are likely to go down. However, occupation and income levels are positively related to satisfaction. Lightner (2003) in his study on online experience using regression, expressed that age is an important factor in determining satisfaction levels and technology perceptions. VanAmburg (2004) conducted a study on 200 companies using the American Customer Satisfaction Index (ACSI) and demonstrated that age has a significant effect on satisfaction. Younger age groups are less satisfied than older age groups across all products and services industries.

\section{EMPIRICAL REVIEWS ON SERVICE DIMENSIONS}

Martins Balasa, Idris conducted a study on Artisans' Service Quality and Customer Satisfaction using SERVQUAL Model. Survey design was adopted for the study. Data were analysed using paired t- test and regression analysis to test the three hypotheses of the study. The results showed that SERVQUAL dimensions can measure customer satisfaction. Tangibility, Responsiveness, Assurance and Empathy dimensions have a strong positive predictive power on satisfaction in the North Eats of Nigeria. The result further show that reliability dimension fail to show any significant impact on customer satisfaction in the North East of Nigeria, and this is attributed to integrity and reliability problems customers pass through in the hands of artisans. The study further shows that there is a statistically significant difference between the core dimension of service quality and satisfaction. It is concluded that SERVQUAL model is a good measure of artisans' service quality and customer satisfaction in the North East of Nigeria. The measurement can be used to close the gap between customers' perceptions and expectations with the services of artisans in the North East of Nigeria. It is recommended that Artisans need to revamp their prevailing image on reliability dimension, and the measurement of service quality be repeated from time to time by artisans for continuous service improvement. 
Maria-Friday, et al study investigated the relationship between service quality dimensions and customer loyalty in the Nigerian Telecom market with particular interest in identifying if customer satisfaction plays a mediating role. Hypotheses were formulated vis-a-vis theoretical background and conceptual models. A survey data generated from 183 experienced telecom customers were used as the research database. The study utilized SERVPERF measuring scale for adaptability and Correlation techniques in analyzing the data. Basically, it was discovered that the empathy dimension of service quality has a strong and positive relationship with customer loyalty and customer satisfaction.

Service reliability and assurance loaded together shows evidence of strong positive relationship with customer satisfaction with an aggregate of 0.254 at $\mathrm{P}<0.01$. which means that an increase in the perception of the reliability and assurance dimensions increase customer satisfaction. The empathy dimension also indicates a strong positive relationship between the construct and customer satisfaction with an aggregate value of 0.220 at $\mathbf{P}<0.003$. This means that this construct is statistically significance at 0.003 level, in other words, an increase in the empathy dimension would lead to an increase of satisfaction up to $22 \%$.

Service Dimensions and Customer Loyalty pulled an aggregate of 0.281 at a significant level of 0.000 . The significance level indicates that network quality is an important variable in determining customer loyalty. That is, if service quality is increased by $28 \%$, loyalty will increase by $28 \%$. On the other hand, service empathy showed a strong positive relationship with customer loyalty. It pulled an aggregate of 0.337 at a significant level of 0.00 . This means that customer loyalty will increase by $34 \%$ if the perception of the service empathy variable is increased by $34 \%$. It also portrays the fact that service empathy is important in determining customer loyalty.

The ANOVA explained that overall model was significant. Since the sig. value is less than 0.05 so it indicates that the model is statistically significant. It is strong that all the independent variables, that is, customer service, price fairness, sales promotion, coverage and promotion are connected to the dependent variable, that is, customer satisfaction. Among all variables, price fairness is the major variable with standardized coefficient $b=240$ that can satisfy the customer toward their particular service provider. While coverage is the second momentous variable with a standardize coefficient of $b=0.224$. Furthermore with a standardize coefficient 0.160 , customer service is the third variable that can influence customer satisfaction in cellular industry. Remaining variables such as signal strength $(b=0.013)$, sales promotion $(b=0.012)$ and promotion $(b=0.096)$ are comparatively less influenced customer satisfaction in cellular industry. According to Shahzad Khan, et al (2012), It was concluded that price fairness and coverage are the key factors contributing towards customer satisfaction of University students.

\section{CONCLUDING REMARKS}

With this aforementioned literature, it is noted that customers purchase services based on their needs and have expectations that the purchased services will meet their needs. Customers in turn assess the service performance in accordance to how well it meets their expectations. Satisfaction measurement is useful to understand customer expectations (since most times assessment is done by customers based on past experiences and future beliefs of service performance). In this paper, we have carried out a critical review of literature on the theoretical, conceptual and empirical antecedents of customer satisfaction. Future work will examine how the findings from literature intertwine with productivity and effectiveness of service delivery. 


\section{BIBLIOGRAPHY}

1. Aaker, J.L. (1997) - "Dimensions of brand personality", Journal of Marketing Research 34, August, pp347-356.

2. Ahmad, J. and Kamal, N., 2002- Customer satisfaction and retail banking: an assessment of some the key antecedents of customer satisfaction in retail banking. International Journal of Bank Marketing, 20/4, pp.146-160.

3. Bearden, W.O. and Teel, J.E. (1983) - "Selected determinants of consumer satisfaction and complaint reports”, Journal of Marketing Research, Vol. 20, February, pp. 21-8.

4. Bennett, R. (1986) - Meaning and method in management research. Graduate Management research, 3(3).

5. Bhave, A., 2002- "Customer satisfaction measurement", Quality and Productivity Journal, Symphony Technologies Pvt Ltd, Erendavane, India.

6. Bryant, B.E., and Cha, J., 1996 - Crossing the threshold, Marketing Research, Chicago, Winter,

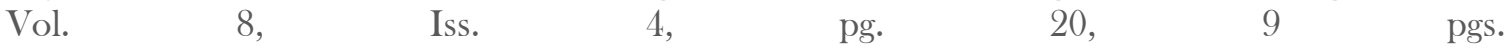
Cadotte, E, R, R.B.Woodruff and Jenkins, R.L (1987)- Expectations and norms in models of consumer satisfaction, journal of marketing research, 24, Aug. pp 305-314.

7. Cadotte, E.R. and Turgeon, N. (1988) - "Key factors in guest satisfaction", Cornell Hotel and Restaurant Quarterly, Vol. 28 No. 4, pp. 45-51.

8. Cardozo, R.N. (1965) - "An experimental study of consumer effort, expectation and satisfaction", Journal of Marketing Research, Vol. 2, pp. 244-9.

9. Churchill, G.A and Surprenant, C (1982) - An investigation into the determinants of customer satisfaction, journal of marketing research, 19, Nov, pp. 491- 504

10. Coyne, K. (1989) - "Beyond service fads- meaningful strategies for the real world", Sloan Management Review, Vol. 30, Summer, pp. 69-76.

11. Dabholkar, P.A., Thorpe, D.I. and Rentz, J.O. (1996) - "A measure of service quality for retail stores: scale development and validation”, Journal of the Academy of Marketing Science, Vol. 24, Winter, pp. 3-16.

12. Danaher, P. J., \& Rust, R. T. (1996) - Indirect financial benefits from service quality. Quality Management Journal, 3(2), pp.63-75.

13. Desai, K.K., and Mahajan, V., 1998- "Strategic role of affect-based attitudes in the acquisition, development and retention of customers”, Journal of Business Research, Vol.42, July, pp.309-24.

14. Dillman, D. (2000) - Mail and Internet Surveys: the tailored design method, $2^{\text {nd }}$ edition, Wiley Cop., NY.

15. Edvardson, B and Gustafsson, A, 1999- The Nordic School of Quality Management, Studentlitteratur, Lund.

16. Edvardsson, B., Johnson, M.D., Gustafsson, A. and Strandvik, T., 2000b- The effects of satisfaction and loyalty on profits and growth: products versus services, Total Quality Management, Vol.11: 7, 917-927.

17. Fornell, C., Johnson, M. D., Anderson, E. W., Cha, J., \& Bryant, B. E. (1996). The American Customer Satisfaction Index: Nature, purpose, and findings. Journal of Marketing, 60(4), 7-18.

18. Gale, B., 1992- Monitoring Customer Satisfaction and Market Perceived Quality, Worth Repeating Series, No. 922CS01, American Marketing Association, Chicago, IL.

19. Gerpott, T. J. (1998)- Wettbewerbsstrategien im Telekommunikationsmarkt (3rd ed.). Stuttgart: Schaffer-Poeschel. 
20. Gerpott, T.J., Rams, W., and Schindler, A., (2001) - "Customer retention, loyalty, and satisfaction in the German mobile telecommunications market, Telecommunications Policy, Vol. 25 No. 4, pp. 249 - 269.

21. Gronhaug, K. (2002) - Research methods in Business Studies: A practical guide, $2^{\text {nd }}$ ed., London: Prentice Hall.

22. Grönroos, C. (1984) - "A service quality model and its marketing implications", European Journal of Marketing, Vol. 18 No. 4, pp. 36-44.

23. Grönroos, C. (1985) - "Internal marketing - theory and practice", in Block, T.M., Upah, G.D. and Zeithaml, V.A. (Eds), Services Marketing in a Changing Environment, American Marketing Association, Chicago, IL, pp. 41-7.

24. GSM Association (2006) - www.gsmworld.com

25. Hair, Jr., J.F., Black, B., Babin, B., Anderson, R.E., and Taltam, R.L. (2005) - Multivariate data analysis. $6^{\text {th }}$ Edition, Prentice Hall, US.

26. Homburg, C., \& Bruhn, M. (1998). Kundenbindungsmanagement - Eine EinfuK hrung in die theoretischen and praktischen Problemstellungen. In M. Bruhn, \& C. Homburg (Eds.), Handbuch Kundenbindungsmanagement (pp. 3\}35).Wiesbaden: Gabler.

27. Howard, J.A. and Sheth, J.N. (1969) - The Theory of Buyer Behavior, John Wiley \& Sons, New York, NY.

28. Hunt, K.H. (Ed.) (1977)- "Conceptualization and Measurement of Consumer Satisfaction and Dissatisfaction”, Marketing Science Institute, Cambridge, MA.

29. Hunt, H.K. (1982) - “ A "10” based on expectations, but normatively a 3.6371”, in Day, R.L. and Hunt, H.K. (Eds), Proceedings of the $7^{\text {th }}$ Annual Conference on Consumer Satisfaction, Dissatisfaction and Complaining Behaviour, University of Tennessee, Knoxville, TN, October, pp. 130-31

30. Hurley, R.H. and Estelami, H. (1998) - "Alternative indices for monitoring customer perceptions of service quality: a comparative evaluation in a retail context", Journal of the Academy of Marketing Science, Vol. 26, Summer, pp. 201-21.

31. Ittner, C. and Larcker, D.F. (1996) - "Measuring the impact of quality initiatives on firm financial performance", in Ghosh, S. and Fedor, D. (Eds), Advances in the Management of Organisational Quality, Vol.1, JAI, Greenwich, CT, pp.1-37.

32. Ittner, C. and Larcker, D.F. (1998)-“Are non-financial measures leading indicators of financial performance? An analysis of customer satisfaction”, Journal of Accounting Research, Vol. 36, Supplement, pp. 1-35.

33. Levesque, T. and McDougall, G.H.G, (1996) - "Determinants of customer satisfaction in retail banking”, International Journal of Bank Marketing, Vol. 14 No. 7, pp. 12-20.

34. Lewis, R.C. (1987) - "The measurement of gaps in the quality of hotel services", International Journal of Hospitality Management, Vol. 6 No. 2, pp. 83-8.

35. Lightner, N. J. (2003) - What users want in e-commerce design: effects of age, education and income. Ergonomics, 46(1-3), 153-168.

36. Lonergan, D., Swain, W., Guy, A., Yunus, F., Jackson, J., Mallinson, K., et al. (2004). Asia-Pacific Region to drive global wireless revenue. The Yankee Group Report, Boston, MA, USA.

37. Lovelock, C.H., Patterson, P.G. and Walker, R.H. (2001) - Services Marketing: Australia and New Zealand, Pearson Education Australia, French's Forest.

38. Malhotra, N., and Birks, D. (2003) - Marketing Research, An applied approach, Harlow, England: Prentice Hall. 
39. Mano, H. and Oliver, R.L. (1993) - "Assessing the dimensionality and structure of the consumption experience: evaluation, feeling and satisfaction, Journal of Consumer Research, Vol.20, Dec., pp.451-66.

40. Maria-Friday Nkwedel, et al - Correlate of Service Quality Dimensions and Customer

41. Loyalty in the Nigerian Telecom Markets: Does Customer Satisfaction Play a

42. Mediating Role? IOSR Journal of Business and Management (IOSR-JBM)

43. e-ISSN: 2278-487X, p-ISSN: 2319-7668. Volume 19, Issue 1. Ver. IV (Jan. 2017), PP

44. 60-71 www.iosrjournals.org

45. Martins, Balasa Idris (2012) - Application of Servqual Model to the Measurement of

46. Artisans, Service Quality and Customer Satisfaction in the North East of Nigeria.

47. Maslow, A.H. (1943) - "A theory of human motivation", Psychological Review, Vol. 1, pp. 370-96.

48. McDougall, G. and Levesque, T. (1992) - "The measurement of service quality: some methodological issues”, 2nd International Research Seminar in Service Management, La-LondeLes Maures, France, pp. 410-31.

49. McNeale, R.M. (1994) - Making customer satisfaction happens. Chapman and Hall, London.

50. Naumann, E. (1995), Customer Satisfaction Measurement and Management: Using the Voice of the Customer, Thomson Executive Press, Cincinnati, OH.

51. Ndukwe, Ernest (2005) - Country experience in telecom market reforms in Nigeria. CEO, Nigerian Communication Commission, July 2005. www.ncc.gov.ng.

52. Oliver, R.L. (1997) - Satisfaction: A behavioural perspective on the consumer, Irwin/ McGraw-Hill, NY.

53. Oliver, R.L. (1999) - "Whence customer loyalty?” Journal of Marketing, Vol. 63, pp. 33-44.

54. Olshavsky, R.W. and Miller, J.A. (1972) - "Consumer expectations, product performance and perceived product quality”, Journal of Marketing Research, Vol. 9, February, pp. 19-21.

55. Olson, J.C. and Dover, P. (1979) - "Disconfirmation of consumer expectation through product trial”, Journal of Applied Psychology, Vol. 64, pp. 179-89.

56. Ovenden, A., (1995) -"Keep your customers happy and your competition will slowly fade away", The TCM Magazine, Vol. 7 No. 1, pp.46-49.

57. Oyewole, P., 2001- Consumer's socio-demographic characteristics and satisfaction with services in the airline industry, services Marketing Quarterly, Binghamton, Vol.23, Iss. 2, pg.61

58. Palvia, P. C., \& Palvia, S. C. (1999) - An examination of the IT satisfaction of small-business users. Information \& Management, 35(3), 127-137.

59. Peterson, R.A. and Wilson, W.R. (1992) - "Measuring customer satisfaction: fact and artifact", Journal of the Academy of Marketing Science, Vol. 20, pp. 61-71.

60. Pizam, A. and Ellis, T. (1999) - "Customer satisfaction and its measurement in hospitality enterprises”, International Journal of Contemporary Hospitality Management 11/7 [1999] 326-339.

61. Platow, M. J., Harley, K., Hunter, J. and Banning, P. (1997) - "Interpreting in-group-favoring allocations in the minimal group paradigm", British Journal of Social Psychology, Vol. 36, pp. 10717.

62. Porter, L.W. (1961) - "A study of perceived need satisfaction in bottom and middle management jobs”, Journal of Applied Psychology, Vol. 45, pp. 1-10.

63. Ravald, A. and Grönroos, C. (1996) - "The value concept and relationship marketing", European Journal of Marketing, Vol. 30 No. 2, pp. 19-30.

64. Rust, R.T. and Oliver, R.L. (1994) - "Service quality insights and managerial implications from the frontier”, in Rust, R.T. and Oliver, R.L. (Eds), Service Quality New Directions in Theory and Practice, Sage, CA. 
65. Rust, R.T. and Subramanian, B., 1992- "Making complaints a management tool", Marketing Management, Vol.1 No.3, pp. 41-5.

66. Swan, J.E. and Oliver, R.L. (1985) -“Automobile buyer satisfaction with the salesperson related to equity and disconfirmation”, in Hunt, H.K. and Day, R.L. (Eds), Consumer Satisfaction and Complaining Behavior, Indiana University Press, Bloomington, IN.

67. Szymanski, D.M. and Henard, D.H. (2001), "Customer satisfaction: a meta-analysis of the empirical evidence”, Journal of the Academy Marketing Science, Vol. 29 No. 1, pp. 16-35.

68. Szyperski, N., \& Loebbecke, C. (1999). Telekommunikationsmanagement (TKM) als betriebswirtschaftliche Spezialdisziplin. Die Betriebswirtschaft, 59, 481$\} 495$.

69. Taylor, S.A. and Baker, T.L. (1994) - "An assessment of the relationship between service quality and customer satisfaction in the formation of consumers' purchase intentions", Journal of Marketing, Vol. 58, Summer, pp. 163-78.

70. Turel, O. and Serenko, A. (2006) - Satisfaction with mobile services in Canada: An empirical investigation, Telecommunications Policy 30 (2006), pp.314-331, 2006.

71. VanAmburg, D. (2004) - Personal communication regarding the ACSI scores for Canadian wireless service providers, September 30. Ann Arbor, MI, USA.

72. Vavra, T.G. (1997) - Improving Your Measurement of Customer Satisfaction: A Guide to Creating, Conducting, Analyzing, and Reporting Customer Satisfaction Measurement Programs, ASQ Quality Press.

73. Venn, S. and Fone, D.L., 2005 - Assessing the influence of socio-demographic factors and health status on expression of satisfaction with GP services, Bradford, Vol. 10, Iss. 2; pg. 118, 8 pgs.

74. Vroom, V., (1964) -"Work and Motivation”, John Wiley \& Sons, New York, NY.

75. Watson, D. (1992)- "Correcting for acquiescent response bias in the absence of a balanced scalean application to class-consciousness; Sociological Methods and Research 21(1), August, pp.52-88.

76. Westbrook, R.A. and Oliver, R.L. (1991) - "The dimensionability of consumption emotional patterns and customer satisfaction”, Journal of Consumer Research, Vol. 18, June, pp. 84-91.

77. Wiele, T. Vander, Boselie, P. and Hesselink, M., 2002- Empirical evidence for the relationship between customer satisfaction and business performance, Managing Service Quality, Vol. 12, No. 3, pp.184-93

78. Zeithaml, V.A., Berry, L.L. and Parasuraman, A. (1996) - "The behavioral consequences of service quality", Journal of Marketing, Vol. 60, April, pp. 31-46.

79. Zineldin, M., (2000) - "TRM Total Relationship Management, Studentlitteratur, Lund. 